\title{
Improved high-throughput screening technique to rapidly isolate Chlamydomonas transformants expressing recombinant proteins
}

\author{
Ashley E. Sproles ${ }^{1,2} \cdot$ Anthony Berndt $^{1,2} \cdot$ Francis J. Fields $^{1,2} \cdot$ Stephen P. Mayfield ${ }^{1,2}$
}

Received: 7 September 2021 / Revised: 17 January 2022 / Accepted: 18 January 2022 / Published online: 7 February 2022

(c) The Author(s) 2022

\begin{abstract}
The single-celled eukaryotic green alga Chlamydomonas reinhardtii has long been a model system for developing genetic tools for algae, and is also considered a potential platform for the production of high-value recombinant proteins. Identifying transformants with high levels of recombinant protein expression has been a challenge in this organism, as random integration of transgenes into the nuclear genome leads to low frequency of cell lines with high gene expression. Here, we describe the design of an optimized vector for the expression of recombinant proteins in Chlamydomonas, that when transformed and screened using a dual antibiotic selection, followed by screening using fluorescence activated cell sorting (FACS), permits rapid identification and isolation of microalgal transformants with high expression of a recombinant protein. This process greatly reduces the time required for the screening process, and can produce large populations of recombinant algae transformants with between 60 and $100 \%$ of cells producing the recombinant protein of interest, in as little as 3 weeks, that can then be used for whole population sequencing or individual clone analysis. Utilizing this new vector and high-throughput screening (HTS) process resulted in an order of magnitude improvement over existing methods, which normally produced under $1 \%$ of algae transformants expressing the protein of interest. This process can be applied to other algal strains and recombinant proteins to enhance screening efficiency, thereby speeding up the discovery and development of algal-derived recombinant protein products.
\end{abstract}

\section{Key points}

- A protein expression vector using double-antibiotic resistance genes was designed

- Double antibiotic selection causes fewer colonies with more positive for phenotype

- Coupling the new vector with FACS improves microalgal screening efficiency $>60 \%$

Keywords Microalgae $\cdot$ Fluorescence activated cell sorting (FACS) $\cdot$ Biotechnology $\cdot$ Bioproducts

\section{Introduction}

Microalgae, which include photosynthetic eukaryotes and cyanobacteria, hold great potential as a source of commercial bioproducts, and are currently gaining popularity in biotechnology applications. The cultivation of microalgae is attractive due to its enhanced sustainability over alternative

Stephen P. Mayfield

smayfield@ucsd.edu

1 The California Center for Algae Biotechnology, University of California, San Diego, La Jolla, CA, USA

2 Division of Biological Sciences, University of California, San Diego, La Jolla, CA, USA sources, where it alleviates environmental issues surrounding land usage, greenhouse gas emissions, and global food demands (Herrero and Ibáñez 2015). Algae can be grown on non-arable land in open ponds or in bioreactors using nonpotable water, and have the potential to directly sequester $\mathrm{CO}_{2}$ from power plant flue gases to reduce carbon emissions (Khoo et al. 2013; Cheah et al. 2014). Their biological features allow cultures to quickly reach high densities, producing larger quantities of biomass per area than plants, and can use resources that do not compete with food crops (Dismukes et al. 2008; Herrero and Ibáñez 2015; MorenoGarcia et al. 2017).

Historically, the interest in cultivating microalgae at large scale was spurred by global environmental concerns over fossil fuel emissions, leading to the development of algae 
as a feedstock for biofuels (Sheehan et al. 1998). However, it quickly became clear that to allow economic viability of algal biofuels, valuable co-products would be required, to offset production costs (Stephens et al. 2010; Wijffels and Barbosa 2010; López Barreiro et al. 2014). Investigations into potential co-products has identified many high-value naturally derived compounds, including proteins, oils, carbohydrates, pigments, and small molecules, that can be sold in a variety of markets, such as specialty chemicals, nutritional supplements, feeds and foods, cosmetics, and pharmaceuticals (León-Bañares et al. 2004; Borowitzka 2013; Chew et al. 2017).

In addition to naturally derived products, some microalgae species have been successfully genetically engineered to modify metabolic pathways or express high-value recombinant proteins. To date, there have been over 40 different therapeutic proteins expressed in algal chloroplasts, with many being viral and bacterial antigens that can be used as vaccines for humans and animals (Dyo and Purton 2018), while many other pharmaceutical products are under investigation (Specht and Mayfield 2014; Kwon et al. 2019; Sproles et al. 2021). Furthermore, algae have been engineered to produce proteins for use as human and animal health supplements, as well as industrial enzymes (Georgianna et al. 2013; Manuell et al. 2007; Rasala and Mayfield 2015). C. reinhardtii is also known to be safe for ingestion, and shown to have beneficial effects on the gastrointestinal health of animals and humans (Murbach et al. 2018; Fields et al. 2020), thus an ideal candidate for producing edible recombinant proteins.

Genetic tools for the green microalga Chlamydomonas reinhardtii have been developed over the last few decades, allowing this species to become a model expression system for bioengineering of high-value products (Merchant et al. 2007; Scranton et al. 2015; de Carpentier et al. 2020). All three of the C. reinhardtii genomes-nuclear, chloroplast, and mitochondria-have now been sequenced and annotated (Vahrenholz et al. 1993; Maul et al. 2002; Merchant et al. 2007), and all are amenable to genetic transformation through various methods (Jinkerson and Jonikas 2015; Kindle et al. 1991; Remacle et al. 2006). To date, expression of recombinant proteins has mainly been reported from transgenes inserted in the chloroplast genome, due to the relatively facile homologous recombination in that organelle, that allows site-directed gene insertion, as well as strong, well characterized endogenous promoters, and eukaryoticlike protein folding cellular machinery that allows resulting proteins to be expressed at $0.2-5 \%$ of total soluble protein (Manuell et al. 2007; Mayfield et al. 2007). In contrast, engineering of the nuclear genome has been more challenging, obtaining much lower recombinant protein accumulationwith reported maxima of only $0.2 \%$ of total soluble protein-due to factors such as positional effects from random integration of genes and associated local chromatin effects,
RNA silencing, as well as potential epigenetic suppression of transgenes (Neupert et al. 2009; Potvin and Zhang 2010). However, chloroplast engineering comes with the drawback of often using light-regulated promoters, and lacking the mechanisms for post-translational modifications such as glycosylation, which is important for many therapeutic proteins (Eichler-Stahlberg et al. 2009; Lingg et al. 2012; Mayfield et al. 2007). Nuclear-integrated transgene expression is therefore more ideal and experiences more stable transgene expression (Harris 2009). Because of these factors, the improvement of nuclear recombinant protein expression is a major focus of algae biotechnology research.

Currently, the most significant bottleneck in this bioengineering process is screening for clones with high expression of the desired product, since recombinant genes are integrated randomly into the genome (i.e., expression is heavily influenced by positional effect). Screening typically involves using a drug resistance gene in the expression cassette, so that algae can first be selected on agar plates containing the appropriate antibiotic (Neupert et al. 2012), and then subsequently screened for recombinant protein accumulation in the resulting colonies. Because only a small percentage of drug-resistant colonies has the potential for high level of recombinant protein production, this protein screening process can be relatively lengthy and time-inefficient as most methods require bulk DNA extraction, PCR, and/or sequencing of individual clones, followed by low-throughput western-blotting to identify the expressed protein (Neupert et al. 2009; Georgianna et al. 2013; Soria-Guerra et al. 2014). Additionally, exonuclease activity can degrade transformed DNA, leading to truncated or damage transgenes before the exogenous DNA integrates into the genome (Jinkerson and Jonikas 2015). This can result in drug-resistant transformants that do not even contain a full recombinant protein gene linked to the drug resistance gene. Depending on vector design, these truncation events represent a substantial percentage of transformants (Gonzalez-Ballester et al. 2011; Meslet-Cladière and Vallon 2011; Zhang et al. 2014), if not a majority of the recovered antibiotic resistant clones (Li et al. 2016). Since at best, $<1 \%$ of algae cells result in successful transformants (Life Technologies Corporation 2013), this means thousands or millions of algae cells need to be screened per transformation to obtain clones with the highest protein expression. Therefore, improving highthroughput screening (HTS) methods for the detection of transgenic cells expressing desired proteins is necessary to advance algae as an efficient system for recombinant protein production.

Previously, most HTS methods for microalgae were developed for the identification of high-lipid producing strains for purposes of producing algae-based biofuels (Xie et al. 2014; Zhang et al. 2014). Nile Red and BODIPY stains are commonly used to fluorescently label algal lipids, allowing 
clones to then be analyzed using fluorescence measurements through flow cytometry, fluorescence-activated cell sorting (FACS), or fluorescent microplate reader assays (Mendoza et al. 2008; Chen et al. 2009; Montero et al. 2011; Pereira et al. 2011; Cagnon et al. 2013; Velmurugan et al. 2013; Xie et al. 2014; Terashima et al. 2015; Yamada et al. 2016; Smalley et al. 2020). More recently, these methods have been employed to examine Chlamydomonas populations for expression of fluorescent reporter proteins as proxy for recombinant protein expression (Rasala et al. 2013; Scranton et al. 2016; Fields et al. 2019). FACS is one of the methods capable of isolating individual cells of interest for further study; however, some reports show that cultures screened through FACS can experience poor survival due to shear stress on the cells, and those surviving may not always be high-expressing clones due to sorting errors from the instrument (Velmurugan et al. 2013; Fields et al. 2019). Therefore, HTS processes for identification of recombinant proteins in microalgae need to be optimized by re-considering vector design, improved antibiotic screening, and better FACS instrument settings, adapted specifically to algal cells.

Here, we describe the design of a double-antibiotic selection vector for the expression of recombinant proteins in Chlamydomonas, that when coupled with antibiotics and FACS screening is able to quickly identify and isolate large populations of Chlamydomonas transformants expressing a fluorescent reporter protein. The use of this new vector and HTS process is highly improved over older methods and can be utilized by the broader research community to enhance screening efficiency, thereby speeding up the discovery and development of algal-derived products.

\section{Materials and methods}

\section{Vector design and cloning}

To address the problem of truncated transgenes and low efficiency of recovered gene-of-interest-expressing clones, an expression vector was developed with the gene of interest flanked by two different drug resistance genes: zeocin resistance (ble2A) and hygromycin resistance (Fig. 1). The upstream promoter is allowed variability; here we constructed the vector using three different promoters: AR1, a basal $r b c s 2$ promoter, and SAP11, a synthetic promoter previously found to drive higher expression than AR1 (Scranton et al. 2016). We also constructed a vector without the promoter region to act as a negative control (NC). A FLAG-tagged, modified green fluorescent protein (GFP), mClover, derived from the pOpt series of vectors, is used as the gene-of-interest to act as a reporter since it is one of the brightest and most photostable GFP variants codon optimized for use in $C$. reinhardtii (Lam et al. 2012; Lauersen et al. 2015). Meanwhile, the downstream beta-tubulin promoter drives the hygromycin resistance cassette, a commonly used tool in Chlamydomonas expression vectors (Berthold et al. 2002; Lauersen et al. 2015). This design supports a high-throughput process by allowing determination of full-length construct integration by observing growth on antibiotic plates, rather than having to perform lengthy primer walk sequencing of each clone, since clones with truncated transgenes would not be able to grow in the presence of both antibiotics.

Components of the vector were derived from the pOpt vector system (Lauersen et al. 2015) and assembled into the pUC19 backbone (Norrander et al. 1983) through PCR with Q5 DNA polymerase and NEBuilder HiFi DNA Assembly Cloning Kit (New England Biolabs; catalog E5520S). Variations in the promoter region were additionally constructed using the same assembly method. All constructs were confirmed by primer walk sequencing of the full constructs; the full list of primers is included with Online Resource 2. Once the sequences were confirmed, plasmid DNA was linearized by restriction digest with $K p n \mathrm{I}$ and $\mathrm{X} b a \mathrm{I}$ (New England Biolabs). The digest was then purified using the Wizard® SV Gel and PCR Clean-Up System (Promega), and DNA was quantified using Qubit dsDNA HS Assay Kit (Thermo Fisher Scientific). The vectors were then transformed into chemically competent $E$. coli cells (5-alpha High Efficiency, New England Biolabs) and verified by Sanger sequencing through the entirety of the Chlamydomonas-specific sequences between the M13 Forward and M13 Reverse universal primer sites of the pUC19 vector backbone. Complete vector sequences have been submitted to NCBI (GenBank Accession \#: OK247606 (pAES8; SAP11), OK247607 (pAES7; no promotor), OK247608 (pAES6; rbcs2), OK247609 (pAES5; AR1).

\section{Transformation into Chlamydomonas reinhardtii}

Cultures of wild-type (WT) C. reinhardtii strain CC125 (obtained from chlamycollection.org) were grown and

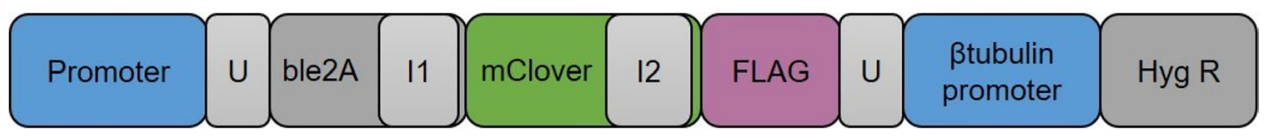

Fig. 1 Design of double-antibiotic resistance expression vector. The variable "Promoter" region is upstream of the rbcs 2 5' and 3' UTRs (U). The ble $2 A$ gene for zeocin resistance is fused to an mClover reporter with the first (I1) and second (I2) rbcs2 introns. A FLAG tag is included upstream of a beta-tubulin promoter driving the hygromycin resistance cassette. Figure created with Microsoft Office 
transformed via electroporation using modified methods of Rasala et al. (2012). Cells were grown under $100 \mu \mathrm{mol} \mathrm{m}{ }^{-2} \mathrm{~s}^{-1}$ light and maintained at $25^{\circ} \mathrm{C}$ on a shaker table at 125 RPM. Once cells reached $0.5-1 \times 10^{6}$ cells $/ \mathrm{mL}$, they were harvested by resuspending to $1-2 \times 10^{8}$ cells/ $\mathrm{mL}$ in GeneArt ${ }^{\circledR}$ MAX Efficiency ${ }^{\circledR}$ Transformation Reagent (Invitrogen). For each vector, $2 \mu \mathrm{g}$ linearized DNA was added to $250-\mu \mathrm{L}$ algae cells and transferred to a 4-mm cuvette, then incubated on ice for $5 \mathrm{~min}$. An electric pulse of $500 \mathrm{~V} / \mathrm{cm}$ was applied to each sample using a Gene Pulser Xcell $^{\mathrm{TM}}$ Electroporation System (Bio-Rad). The capacitance was set at $50 \mu \mathrm{F}$ and resistance at $800 \mathrm{Ohm}$. Cuvettes were immediately transferred to a $25^{\circ} \mathrm{C}$-water bath for $15 \mathrm{~min}$, and then recovered for $18 \mathrm{~h}$ in $10 \mathrm{~mL}$ of TAP (Tris-acetatephosphate) $+40 \mathrm{mM}$ sucrose under lowered light conditions $\left(\sim 85 \mu \mathrm{mol} \mathrm{m}^{-2} \mathrm{~s}^{-1}\right)$.

\section{Screening with antibiotic selection}

The entire population of algae transformants were initially screened by plating a 1:20 diluted culture on TAP/agar plates containing a single antibiotic ( $30 \mu \mathrm{g} / \mathrm{mL}$ hygromycin) and plating undiluted culture on TAP/Agar plates containing two antibiotics ( $30 \mu \mathrm{g} / \mathrm{mL}$ hygromycin $+15 \mu \mathrm{g} / \mathrm{mL}$ zeocin), to compare differences between single (Hyg) and double (Hyg + Zeo) antibiotic selection. Plating was designed this way to plate entire transformation between both treatments while maintaining well-separated colony growth, based on previous unpublished observations of colony frequencies on each plate type.

\section{Screening with fluorescence-activated cell sorting (FACS)}

After 9 days of growth under $100 \mu \mathrm{mol} \mathrm{m}^{-2} \mathrm{~s}^{-1}$ light, antibiotic plates had formed algal colonies that were scraped into 50 -mL sterile tubes containing $20 \mathrm{~mL}$ TAP using a rubber spatula. The liquid cultures were incubated under the same light conditions on shaker table for 4 days to allow cell proliferation for screening with FACS.

One day prior to analysis with FACS, algae cultures were passed through $40-\mu \mathrm{m}$ cell strainers into new sterile $50-\mathrm{mL}$ tubes to remove any agar debris and break-up cell clumps. One hour prior to analysis with FACS, $3 \mathrm{~mL}$ of each culture was added to a $5-\mathrm{mL}$ round bottom polystyrene test tube with 35- $\mu$ m cell strainer cap. A Beckman Coulter MoFlo Astrios with a 100-um nozzle and BioSure ${ }^{\circledR}$ PreservativeFree Sheath Solution was used to collect flow cytometry (FC) data and sort algae cells. This analysis utilized a 488$\mathrm{nm}$ laser with SSC and FSC detection, as well as a 513/26 (FL10) filter to detect mClover fluorescence and a 710/45 (FL9) to detect chlorophyll autofluorescence. To identify transgenic cells positive for the mClover reporter protein, a sample of $C$. reinhardtii $\mathrm{CC} 125$ was analyzed and used to create a gate for the mClover negative $(-)$ population. A gate was then placed further along the mClover axis to identify cells with fluorescence higher than WT, which indicate they are positive $(+)$ for the reporter protein.

The top $10 \%$ of the mClover + cell populations were sorted into six-well plates filled with $3 \mathrm{~mL}$ TAP per well. Number of cells sorted ranged from 1.9 to $10 \mathrm{~K}$ and was dependent on population density (Table 1). Cells were grown in the plates under the same light conditions for 4 days, and then FC data was obtained for each enriched population and analyzed using FlowJo X. Cells within the mClover + gate were exported as individual events, and the mClover fluorescence was normalized to chlorophyll to give relative fluorescence units (RFU). An unpaired two-tailed $t$ test was performed using Microsoft Excel version 2019, to compare RFU between Hyg and Hyg + Zeo populations for each vector, both before and after FACS enrichment. Ten thousand cells from the mClover + populations of the enriched samples were sorted into new $50-\mathrm{mL}$ culture tubes containing fresh TAP, allowed to grow for 1 week, then divided into aliquots that were either re-plated on hygromycin for colony picking, or pelleted and stored in $1-\mathrm{mL}$ fractions at $-80^{\circ} \mathrm{C}$ to use for DNA extraction and Western blots.

\section{Verification of recombinant $\mathrm{mClover}$}

\section{Fluorescence measurements}

Transgenic algae containing the AR1 construct was selected for visualization of recombinant GFP, since it is the most commonly used promoter in Chlamydomonas research and can be used as a control in further studies. After re-plating the enriched cultures, 24 of the resulting single colonies were randomly picked into 96 -well plates filled with $150 \mu \mathrm{L}$ TAP media along with 24 colonies of the CC125 strain for reference. Cultures were incubated in the light for 3 days, then sub-cultured into new plates to remove cell clumps, and analyzed with a TECAN plate

Table 1 Resulting colonies of algal transformants per construct, after 9 days of growth on agar plates containing a single antibiotic (hygromycin only; Hyg) and two antibiotics (hygromycin+zeocin; Hyg + Zeo)

\begin{tabular}{llll}
\hline Vector & $\begin{array}{l}\text { Total colonies on Hyg } \\
(\% \text { mClover }+)\end{array}$ & $\begin{array}{l}\text { Total colonies } \\
\text { on Hyg +Zeo } \\
(\% \text { mClover }+)\end{array}$ & $\begin{array}{l}\text { Hyg:Hyg + Zeo } \\
\text { colony ratio }\end{array}$ \\
\hline NC & $1672(0.3 \%)$ & $18(85.2 \%)$ & $4180: 1$ \\
rbcs2 & $840(2.7 \%)$ & $268(62.9 \%)$ & $160: 1$ \\
AR1 & $2116(3.1 \%)$ & $310(62.7 \%)$ & $272: 1$ \\
SAP11 & $1776(3.4 \%)$ & $193(61.0 \%)$ & $470: 1$ \\
\hline
\end{tabular}


reader. Fluorescence of mClover was measured at an excitation/emission wavelength of 505/540 $\mathrm{nm}$ and was normalized by chlorophyll measurements at $440 / 680 \mathrm{~nm}$ as shown in Online Resource 1. Fold change of mClover over WT algae was calculated, and one high-expressing clone ( 8X higher mClover than WT, called AR1_D12) capable of long-term survival on archive plates was used for imaging. Differential interference contrast (DIC) and fluorescence microscopy were performed using a DeltaVision Core system (Applied Precision) composed of an Olympus IX71 inverted microscope equipped with Olympus UPlanSApo $100 \times / 1.40$ objective and $1.6 \times$ auxiliary magnification enabled, with a CoolSNAP HQ2/ICX285 camera. Tetramethylrhodamine isothiocyanate (TRITC) filters (EX555/28 and EM617/73) were used to image autofluorescence of photosynthetic pigments, while the GFP (EX470/40 and EM525/36) filters were used to image heterologous protein fluorescence. Image acquisition, deconvolution, and analysis were performed using Resolve3D softWoRx-Acquire (Version 5.5), and ImageJ was used for brightness/contrast adjustments and figure panel construction. Exposure times were consistent for all samples as follows: DIC $=50 \%$ transmission, 0.4 -s exposure, $\mathrm{GFP}=100 \%$ transmission, 0.3 -s exposure, $\mathrm{TRITC}=100 \%$ transmission, 2-s exposure.

\section{DNA extraction and sequencing}

Cells sorted from the enriched culture were grown in the light for 4 days, then $1 \mathrm{~mL}$ of algae from each culture was centrifuged for $5 \mathrm{~min}$ at $5000 \times g$ at room temperature (RT). The supernatant was removed, and the algal pellet was used for genomic DNA extraction by adding $650 \mu \mathrm{L}$ of warm $\left(65^{\circ} \mathrm{C}\right)$ LDS lysis buffer $(1 \%$ lithium dodecyl sulfate; $20 \mathrm{mM}$ Tris-HCl, $\mathrm{pH} \mathrm{8.0;} 2 \mathrm{mM}$ sodium EDTA, pH 8; $500 \mathrm{nM}$ $\mathrm{NaCl}$ ) and incubating in a $6{ }^{\circ} \mathrm{C}$-water bath for $20 \mathrm{~min} .650$ $\mu \mathrm{L}$ of phenol:chloroform:isoamyl alcohol $\mathrm{pH} 8$ was added, and lysate was shaken to emulsion for $\sim 10 \mathrm{~s}$. Samples were spun at $5000 \times g$ for $4 \mathrm{~min}$ at room temperature (RT), then $500 \mu \mathrm{L}$ of the upper aqueous phase was recovered and mixed with $750 \mu \mathrm{L}$ of ethanol-stabilized chloroform. After centrifugation at $16,000 \times g$ for $1 \mathrm{~min}$ at $\mathrm{RT}, 400 \mu \mathrm{L}$ of the upper aqueous phase was recovered and washed with 750 $\mu \mathrm{L}$ ethanol-stabilized chloroform for a second time. $300 \mu \mathrm{L}$ of the aqueous phase was then recovered and $1 \mu \mathrm{L}$ of $5 \mathrm{mg} /$ $\mathrm{mL}$ linear polyacrylamide was added and vortexed to mix. Next, $300 \mu \mathrm{L}$ of isopropanol was added to precipitate DNA, and samples were centrifuged for $30 \mathrm{~min}$ at $16,000 \times g$ for $30 \mathrm{~min}$. Once the supernatant was removed, the DNA pellet was washed twice with $1 \mathrm{~mL}$ of $70 \%$ ethanol. DNA was then dissolved in $150 \mu \mathrm{L}$ of $1 \mathrm{X} \mathrm{TE} \mathrm{pH}$ 8. DNA concentration was quantified with Qubit dsDNA HS Assay Kit (Thermo Fisher Scientific) then amplified with PCR.
Q5 Hot-Start Polymerase (New England Biolabs) was used to amplify vectors from algal genomic DNA in $50-\mu \mathrm{L}$ reactions. Thermocycling was conducted with initial denaturation at $98^{\circ} \mathrm{C}$ for $30 \mathrm{~s}$, followed by 35 cycles of $98{ }^{\circ} \mathrm{C}$ for $10 \mathrm{~s}, 62^{\circ} \mathrm{C}$ for $20 \mathrm{~s}, 72{ }^{\circ} \mathrm{C}$ for $20 \mathrm{~s}$, with final extension at $72{ }^{\circ} \mathrm{C}$ for $2 \mathrm{~min}$, and an indefinite hold at $4{ }^{\circ} \mathrm{C}$. Primers were designed to amplify only the variable promoter region of each vector. The forward primers AES51_F1 (AATTCG CGATTATAACGGC), AES61_F1 (AATTCGCGATTA TAACCGG), AES71_F1 (AATTCGCGATTATAAGAG AAGTC), and AES81_F1 (AATTCGCGATTATAACAC ATGC) were used to amplify AR1, rbcs2, NC, and SAP11 vectors, respectively. The reverse primer AES51_R1 (GGT CAGCTTGGCCAT) was used to amplify all promoters. Purified PCR products were sequenced using AES910_F1 (ATTTAAATTCGCGATTATAA) and AES51_R1 $10 \mathrm{mM}$ primers, and resulting sequences were assembled to the reference vectors using DNAbaser software.

\section{Western blotting}

Frozen pellets of sorted transgenic algae populations containing each construct were thawed, then resuspended and lysed in 1X BugBuster Protein Extraction Reagent with $0.06 \%$ Benzonase ${ }^{\circledR}$ endonuclease for $10 \mathrm{~min}$ on ice. Lysate was centrifuged at $5000 \times g$ for $5 \mathrm{~min}$ at $4{ }^{\circ} \mathrm{C}$ to pellet cell debris, then supernatant was recovered as clarified lysate. Total soluble protein (TSP) concentration was measured using the Thermo Scientific ${ }^{\mathrm{TM}}$ Coomassie (Bradford) Protein Assay Kit as per the manufacturer's instructions. Lysates were then normalized to $3 \mu \mathrm{g}$ TSP and mixed with $4 \times$ Laemmli buffer with $10 \%$ vol/vol $\beta$-mercaptoethanol. Samples were heated in an $80{ }^{\circ} \mathrm{C}$-water bath for $10 \mathrm{~min}$ then allowed to cool. Proteins were separated by SDS-PAGE on $12 \%$ Mini-PROTEAN® TGX ${ }^{\mathrm{TM}}$ Precast Protein Gels at $200 \mathrm{~V}$, then transferred onto nitrocellulose membrane at $15 \mathrm{~V}$ for $1 \mathrm{~h}$. After blocking with TBSMT $+1 \%$ PVP-40 (Haycock 1993), membranes were probed with an anti-GFP monoclonal antibody conjugated to alkaline phosphatase (abcam, ab6661). The AccuRuler RGB Plus protein marker was used for reference band sizes, while wild-type $C$. reinhardtii strain CC125 was used as a negative control, and the high GFPexpressing single clone from the AR1 construct was used as a positive control.

\section{Results}

Between 900-2000 transformants from Hyg selection and 10-100 transformants from Hyg + Zeo selection were harvested from each of the four different constructs for initial flow cytometry analysis (Table 1). Higher colony frequencies were observed on Hyg plates compared to Hyg + Zeo 
plates for each construct, as expected. DNA sequencing of the sorted cell populations confirmed that the transformants had the intended sequences after FACS enrichment, with the NC vector containing no PCR product. Western blot analysis showed that all enriched transgenic algae cultures were producing recombinant $\mathrm{mClover}$, which has a size of $\sim 41 \mathrm{kDa}$ when fused with Ble, with the NC having only a faint signal under both antibiotic treatments (Fig. 2). Expression of the fluorescent reporter protein can also be confirmed visually in the nucleus when observed by fluorescence microscopy (Fig. 3).

The first round of FACS revealed that hyg transformants had a $<4 \%$ mClover-positive $($ mClover + ) population, while hyg + zeo transformants had between 16 and $29 \%$ mClover + populations (Table 1, Fig. 4). These values increased after FACS enrichment up to $63 \%$ in Hyg transformants and 99\% in Hyg + Zeo transformants (Fig. 4).

The relative fluorescence of mClover + cells was significantly different between hyg and hyg + zeo-screened transformants prior to FACS enrichment for all vectors $(p<0.01)$, with only the rbcs 2 vector having higher expression in the hyg + zeo vs the hyg population (Fig. 5). However, after FACS enrichment, all of the vectors other than the $\mathrm{NC}$ had significantly higher mClover fluorescence $(p<0.01)$ in the hyg + zeo populations (Fig. 5). With the $\mathrm{NC}$ vector being a negative control lacking a promoter to drive the ble $2 a$ gene, its inability to be enriched is not surprising. The promoter-less vector was used here as a control, where expression of the gene would result only if the cassette landed in a region of the genome that could support transcription of the recombinant gene. This is not expected to be a common event, and hence the resulting low number of colonies on hyg + zeo plates was expected.

\section{Discussion}

The higher RFU of the hyg + zeo-screened transformants only after FACS enrichment shows that the double antibiotic screen more efficiently isolates clones with higher expression of mClover. Three of the vectors resulted in hyg-screened transformants with higher mClover RFU than hyg + zeo transformants before FACS enrichment; therefore, sorting for the top $10 \%$ of these populations should have resulted in higher RFU in the enriched culture as well. However, after FACS enrichment, all the promotercontaining vectors experienced higher mClover RFU in the hyg + zeo-screened populations. This indicates that the transformants sorted from the hyg mClover-positive population may have contained truncated transgenes, or perhaps these clones lost mClover expression over time due to rapid gene silencing. Previous studies have found that C. reinhardtii transgenes commonly become silenced from 20 to 200 days after transformation (Koblenz et al. 2003; Iomini et al. 2006). Yamasaki et al. (2008) found that this silencing is due to epigenetic effects that evolved in the algae to protect against viruses and transposable elements, and that subclones can fluctuate in their degree of transgene silencing throughout mitotic cell division. Therefore, our selection method is potentially screening out the transformants with less epigenetic silencing. Additionally, the expression of the hygromycin resistance gene has been observed as extremely unstable even when the associated exogenous gene expression is not (Ladygin and Boutanaev 2002), and could explain why the addition of a second antibiotic resistance gene provides better results.

The synthetic algae promoter, SAP11, was previously shown to drive expression of a fluorescent reporter protein
Fig. 2 Western blot of transgenic algae cultures after FACS enrichment, compared to WT CC125 strain and high GFPexpressing clone AR1_D12 confirmed via microscopy. Hyg, hygromycin screened only, $\mathrm{HZ}$ hygromycin + zeocin screened. The mClover-Ble protein is $\sim 41 \mathrm{kDa}$

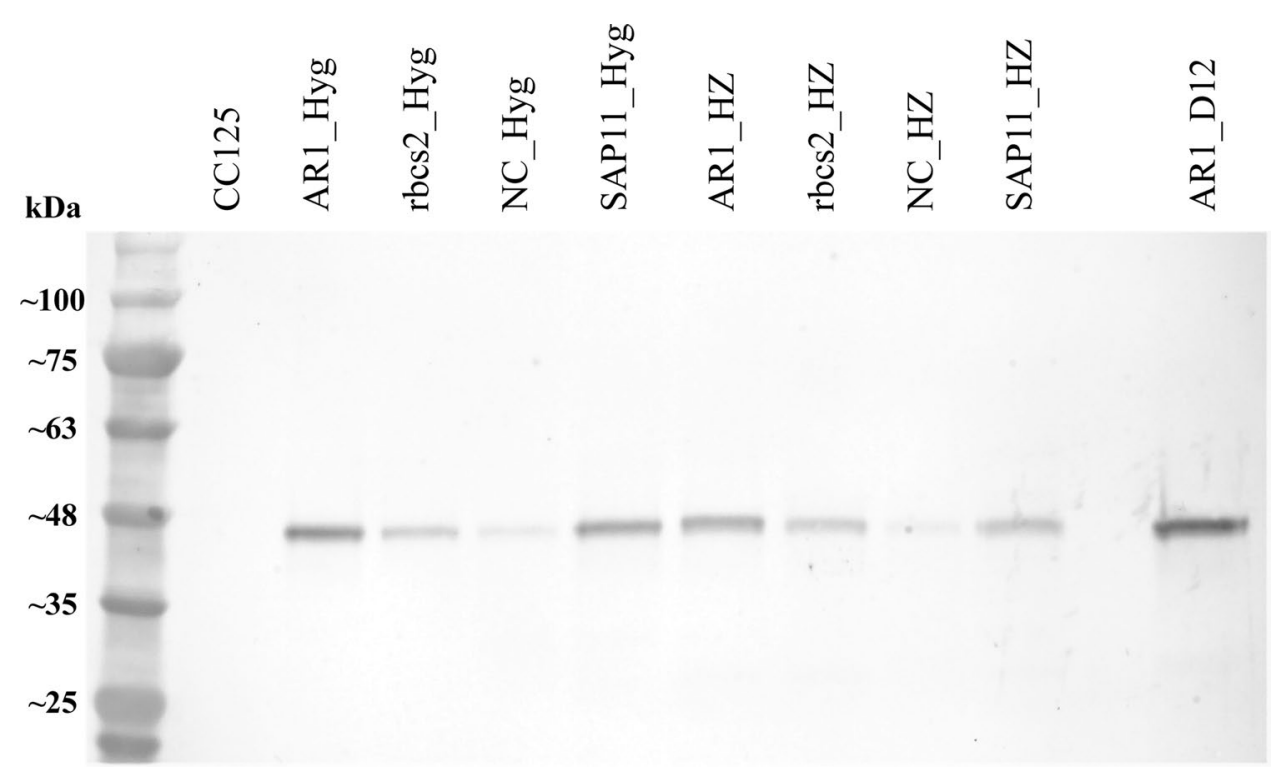



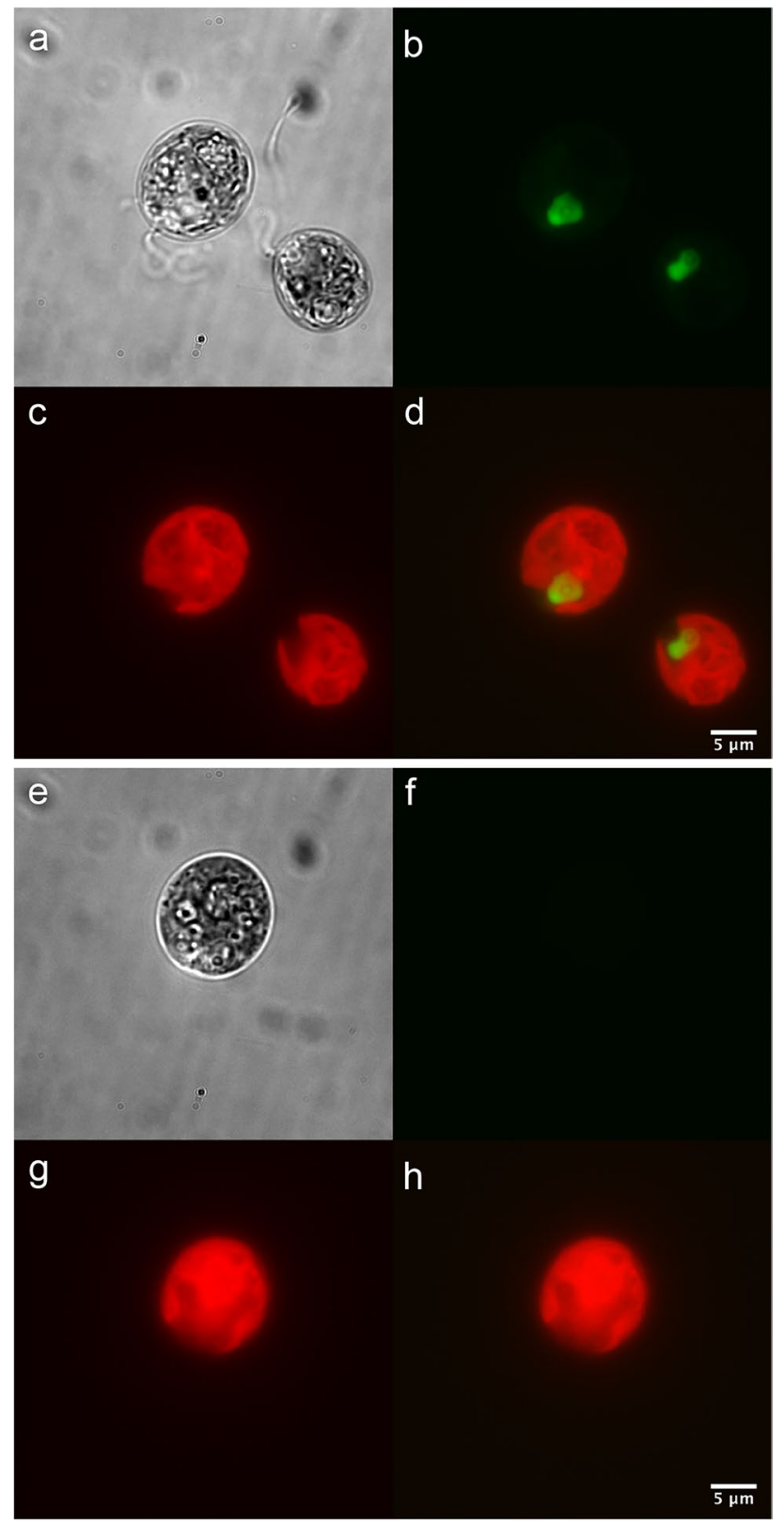

Fig. 3 DIC and fluorescence microscopy images of transgenic $C$. reinhardtii, clone AR1_D12, expressing mClover in the nucleus (a-d) compared to wild-type $C$. reinhardtii strain $\mathrm{CC} 125$ (e-h). a, e Cells observed under DIC. b, f Cells observed under GFP filters. c, g Chlorophyll autofluorescence of cells, observed under TRITC filters. $\mathbf{d}$, $\mathbf{h}$ Merging of GFP and chlorophyll channels. GFP channels were all set to the same contrast (bracketed on raw pixel values of 50-2000) for both transgenic and WT strains, while the chlorophyll channel was similarly bracketed for all images (50-250 raw pixel values). Imaging performed by Ryan Simkovsky (UCSD)

up to $2 \times$ higher than that of AR1 (Scranton et al. 2016). However, when used in our HTS process, it did not result in as many mClover + transformants as AR 1 after FACS enrichment, nor did it drive mClover fluorescence to a degree visibly higher than AR1 (Figs. 4 and 5). In fact, we found that even the $r b c s 2$ core promoter alone resulted in more mClover + transformants with higher mClover RFU than SAP11 after FACS enrichment of the hyg + zeoscreened algae population. Differences may be due to the initial study using a different vector design and $C$. reinhardtii background strain, as well as not conducting FACS enrichment. This synthetic promoter may be less effective at driving recombinant protein expression under these experimental conditions, and follow-up experiments with SAP11 should be conducted to determine its functionality in different strains and vector designs. Interestingly, the differences are not as apparent in the hyg-screened transformants, further demonstrating the utility of the double selection vector in providing more cells for fluorescence assessments, leading to more robust comparisons of vector strengths.

The design of optimized expression vectors for protein expression is critical for improving the efficiency of downstream screening methods by providing a larger population of positive transformants to select from. Furthermore, HTS can be a critical step in the development of bioproducts from microorganisms as it reduces the time and costs of identifying strains with the desired phenotype. FACS has recently become an important tool in the microalgal biotechnology field, as it can be used in bioprospecting for novel strains, achieving axenic cultures, and in strain improvement by enrichment of cells with specific properties; however, the majority of previous studies have focused on screening for lipid-rich microalgae, rather than other gene products and biomolecules (Pereira et al. 2018). The technique has more recently been demonstrated for wider applications, such as screening of the microalga T. lutea, which allowed production of the valuable compounds fucoxanthin (Fx) and docosahexaenoic acid (DHA) to reach industrial levels at outdoor pilot scale after only two rounds of FACS (Gao et al. 2020; Gao et al. 2021). Continued development of FACS methods for screening improved algal strains in this manner will more rapidly advance the field of microalgal biotechnology for a larger diversity of commercial bioproducts.

In more developed recombinant protein production platforms, such as bacteria, screening of clones using antibiotic resistance genes, as well as HTS using fluorescent reporter fusion proteins or fluorescent probes with FACS, has long been utilized to monitor and isolate desired overexpression phenotypes (Makino et al. 2011). In fact, when using GFP as a reporter protein in $E$. coli, it was found that fluorescence correlated well with robust protein folding and expression levels of fused recombinant proteins (Waldo et al. 1999). In these systems, FACS has been used to successfully improve transformant screening for desired targets in multiple different ways. One interesting method for screening enzyme gene libraries is through compartmentalizing either recombinant 


\section{a. Before FACS enrichment}
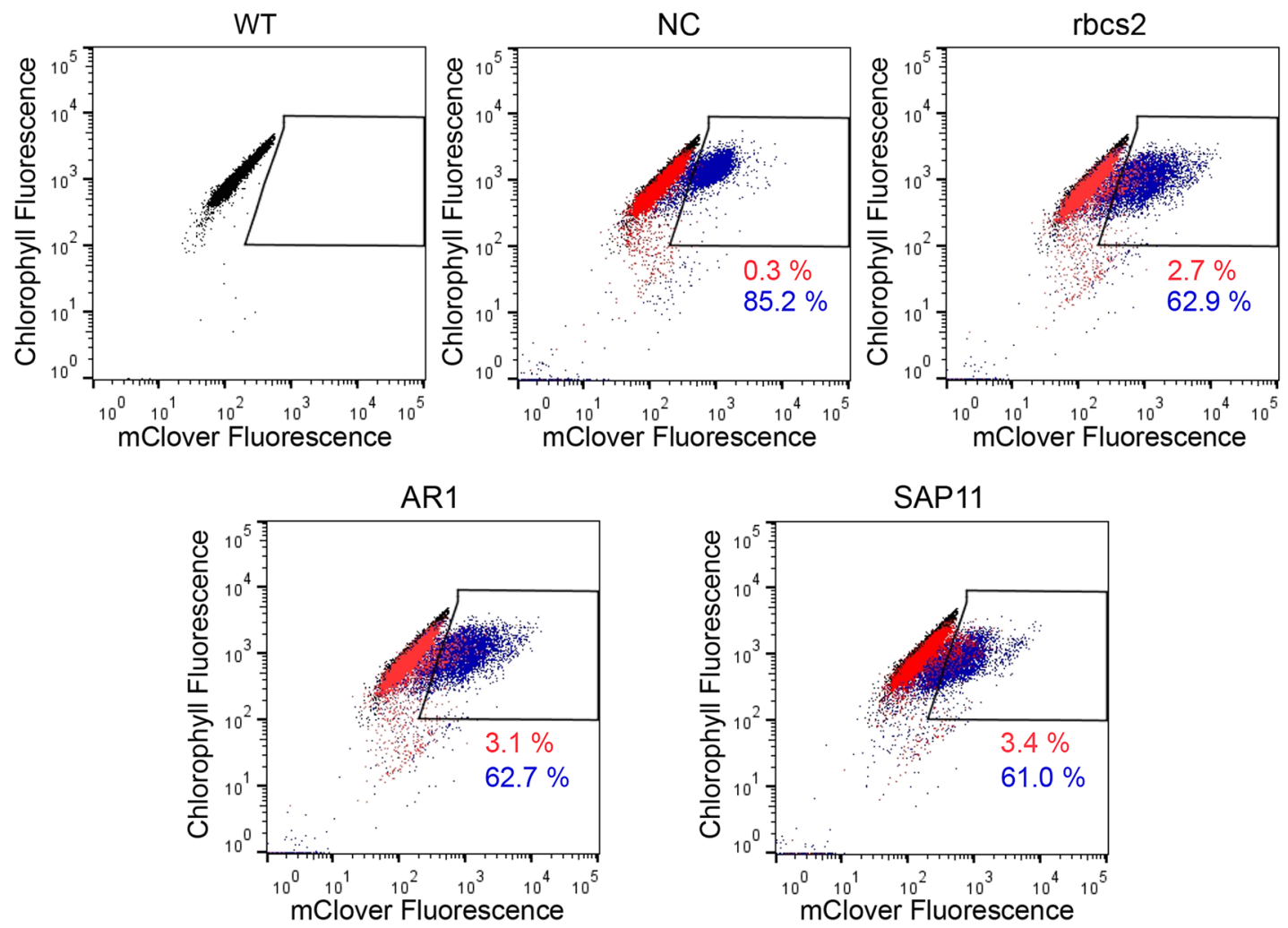

\section{b. After FACS Enrichment}
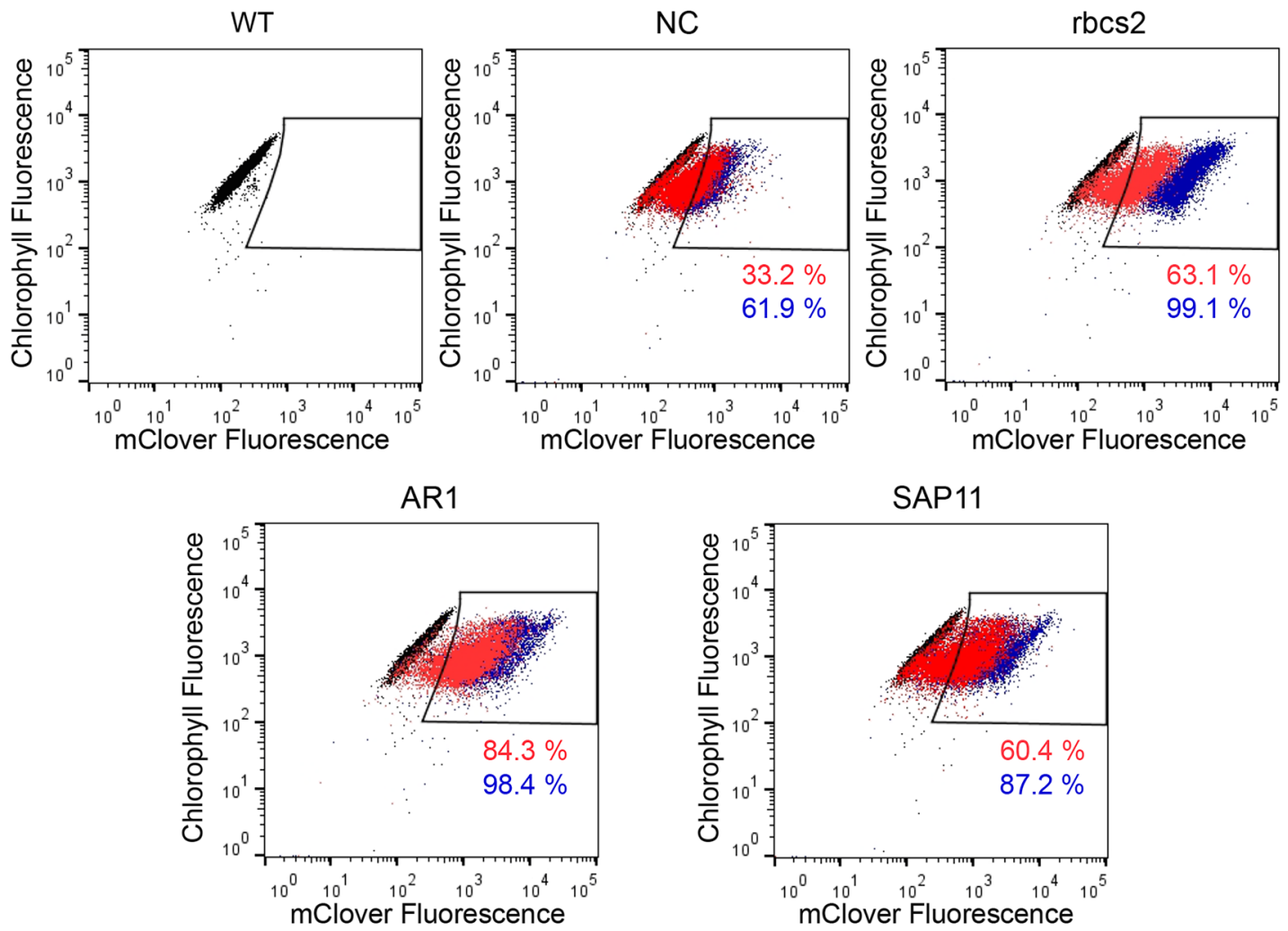

hyg $\square$ hyg+zeo 
4Fig. 4 Effect of FACS enrichment on mClover+cell populations resulting from expression vectors with variable promoter regions. Algae transformants were screened on agar plates containing either hygromycin (red) or hygromycin + zeocin (purple), then surviving colonies were inoculated into liquid culture and analyzed by flow cytometry a 4 days after initial inoculation and b 4 days after sorting the top $10 \%$ of the mClover + population into fresh TAP media. Black populations in each plot show the baseline measurements for wild type (WT) $C$. reinhardtii CC-125. Gates higher on the mClover axis designate populations with mClover+expression. Percentages under gates correspond with the amount of each population that is contained within the mClover+gate. Figure created with FlowJo X and Inkscape

single cells, or cell-free single gene copies, into aqueous water droplets that are then emulsified within oil droplets with a fluorogenic substrate; the enzyme reacts with the substrate and is then double-emulsified into a water-in-oilin-water microdroplet that is then sorted via FACS to isolate and enrich for high enzyme activity (Aharoni et al. 2005; Mastrobattista et al. 2005). Additionally, protein libraries generated using display technologies can also be screened using FACS to link the protein function to the gene encoding that protein. This is achieved through engineering the target protein as fused to a carrier protein that will display it on the cell's outer surface, where it can be labelled with a fluorescent-conjugated ligand and sorted for binding affinity (Daugherty 2007). These methods could be considered as potential avenues to explore enzyme engineering in microalgae as well.

In conclusion, this study describes both an improved expression cassette, and high-throughput screening process, that allows for the rapid identification of robust recombinant protein expression in the green algae Chlamydomonas reinhardtii. Utilizing a double-antibiotic-resistance selection vector, coupled with low pressure FACS, allows for increased post-sort survival of transformants with a high percentage of recombinant protein expression. The process outlined here is able to produce large populations of successful algae transformants with nearly $100 \%$ displaying expression
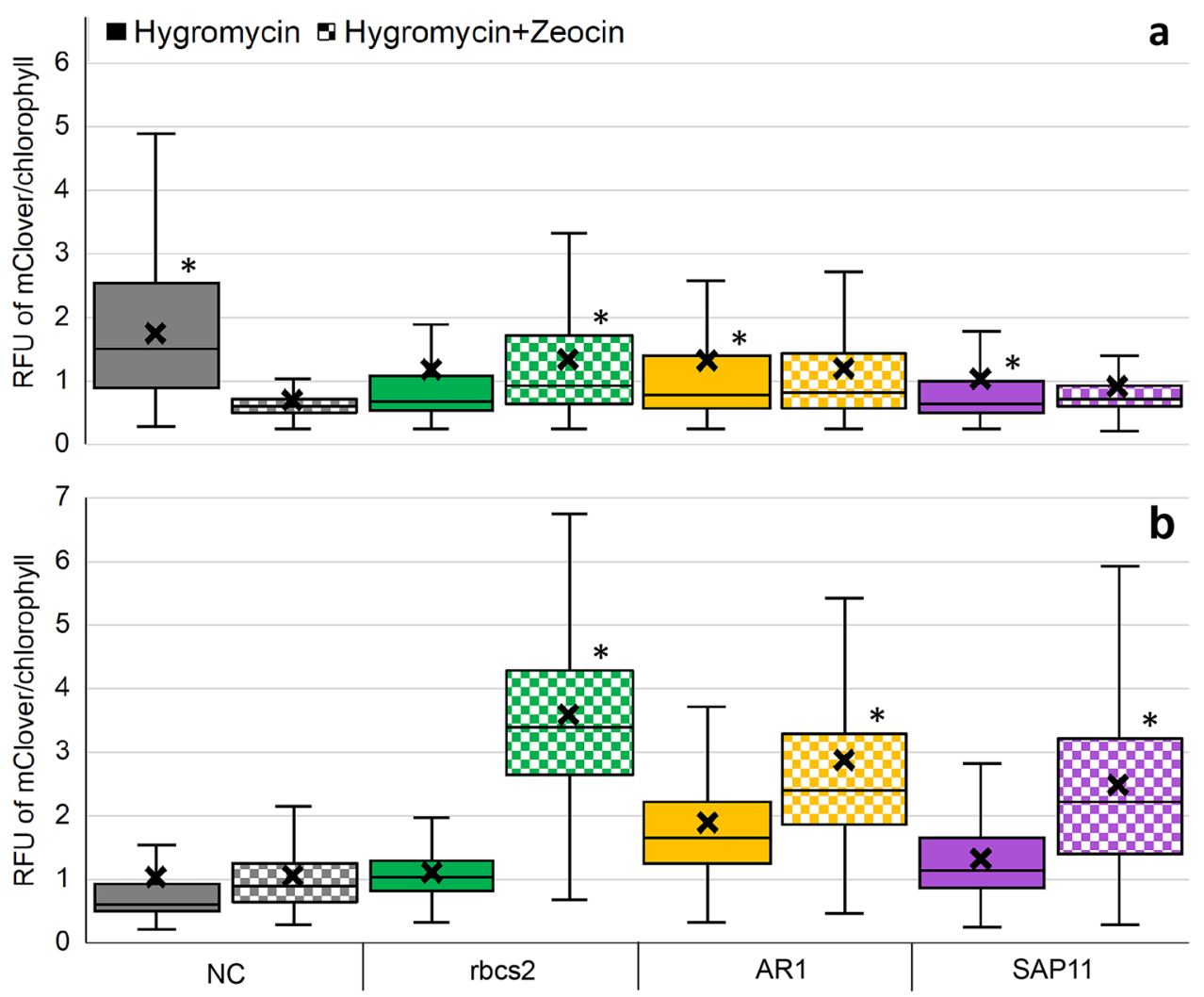

Fig. 5 Flow cytometry data examining the relative fluorescence units (RFU) of mClover normalized to chlorophyll fluorescence in C. reinhardtii. a After transformation with either the $\mathrm{NC}, \operatorname{rbcs} 2, \mathrm{AR} 1$, or SAP11 vector, cells were recovered on agar plates with either hygromycin (solid boxes) or hygromycin + zeocin (checkered boxes) and then examination via flow cytometry. The distribution of the RFU from these initial transformants includes those whose mClover fluorescence was in the region above wild-type autofluorescence. Cells fluorescing in the top $10 \%$ of this region were isolated via fluorescence-activated cell sorting (FACS). b After FACS, cells were again recovered on agar plates with either hygromycin (solid boxes) or hygromycin +zeocin (checkered boxes) and then examination via flow cytometry for a second time. $N=2000$ per box plot, $x$ indicates the mean, and asterisks indicate any significant difference $(p<0.01)$ between mean RFU when comparing antibiotic treatment within respective colored pairs. Figure created with Microsoft Office 


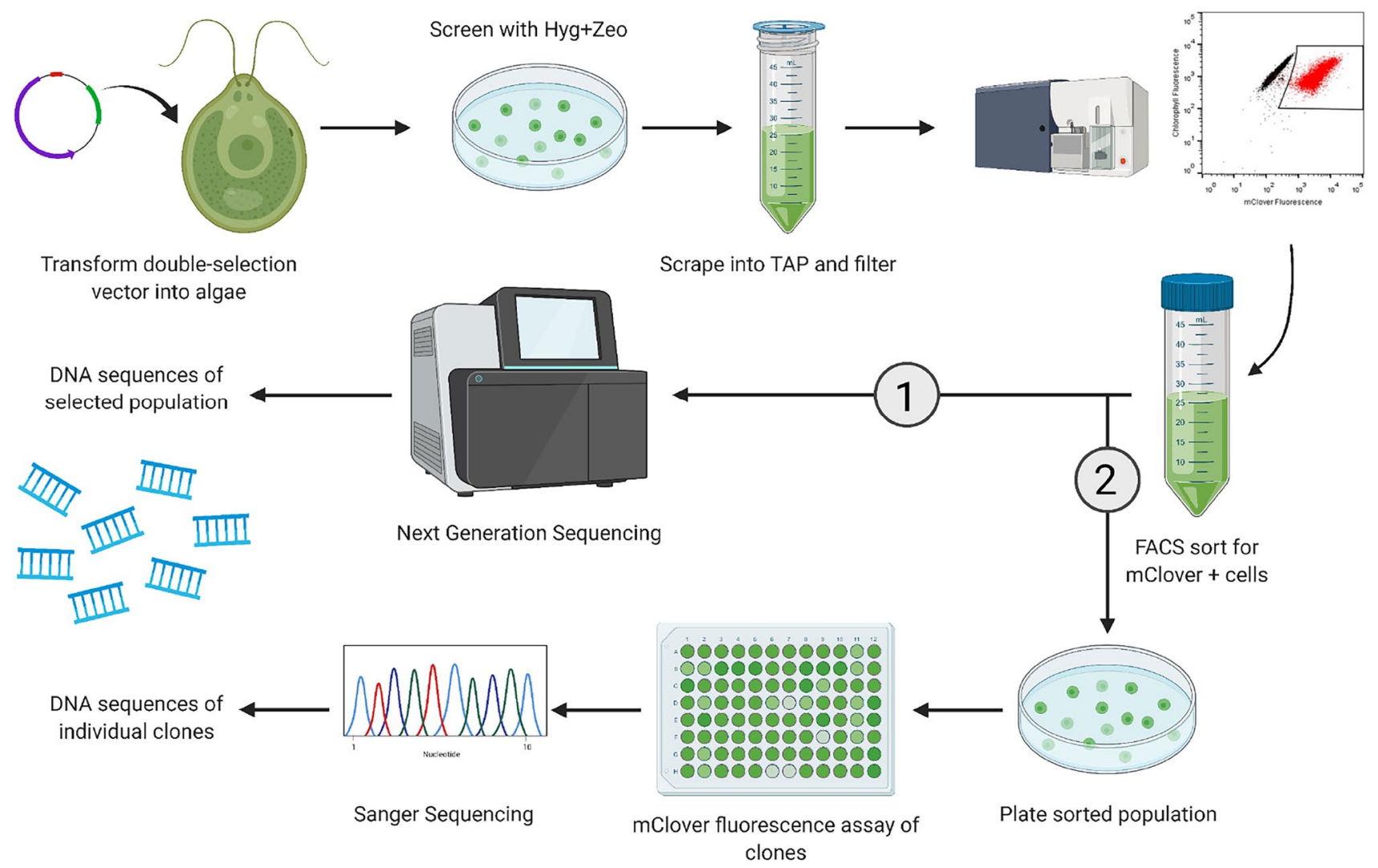

Fig. 6 Overview of new high-throughput screening process using double antibiotic selection and FACS. An expression vector containing an mClover fluorescent reporter protein flanked by zeocin and hygromycin resistance genes is transformed into algae, then screened on agar plates containing both antibiotics. Resulting colonies are inoculated into liquid TAP culture and high-expressing cells

of the protein of interest, in as little as three weeks. These cell populations can then be used for applications such as DNA sequencing of the entire enriched population, which would be especially helpful when screening algae populations containing genetic libraries with next-generation sequencing, and they can be re-plated for picking single colonies for individual clone analysis (Fig. 6). Previous studies have used FACS to screen microalgae for desired phenotypes, but generally result in low yields of positive populations $(<1 \%)$ that results in a more low-throughput and error-prone output (Xie et al. 2014; Fields et al. 2019). Here, we demonstrated that utilizing double selection with both zeocin and hygromycin, as opposed to hygromycin only, prior to FACS, we were able to significantly increase the percentage of transformants expressing the reporter protein from less than $5 \%$ to over $60 \%$. Only one round of FACS enrichment was required to improve the reporter expression to nearly $100 \%$ of transformants in the hyg + zeo-screened populations. Standardization of flow cytometric methods and rapid identification of the desired traits will be essential to are sorted by FACS. The enriched culture can be used for (1) whole population sequencing to detect genetic variability or (2) re-plated for picking colonies into microplates for individual fluorescence measurements and sequencing of clones of interest. Figure created with Biorender.com

developing feasible bioprocesses in any algae production platform (Hyka et al. 2013). To further advance the development of high-value recombinant proteins in microalgae, the optimized HTS process we describe here can be utilized and adapted by other research groups studying recombinant proteins in microalgae to identify and isolate large populations of successful transformants, ideally demonstrating the versatility of the method with various background strains and target products.

Supplementary Information The online version contains supplementary material available at https://doi.org/10.1007/s00253-022-11790-9.

Acknowledgements We would like to thank Ryan Simkovsky for DIC and fluorescence microscopy imaging of our samples for this project, and the flow cytometry core facility at The Scripps Research Institute (TSRI) for assistance in FACS sorting.

Author contribution All authors contributed to the study conception and design. Material preparation, data collection, and analysis were performed by AES, AB, and FJF. The first draft of the manuscript was written by AES, while AB, FJF, and SPM contributed to revisions of the manuscript. All authors read and approved the final manuscript. 
Funding Funding was provided by the U.S. Department of Energy, as part of the PEAK (DE-EE0008246) and BEEPS (DE-EE0008491) projects.

Data availability All data generated or analyzed during this study are included in this article and associated supplementary information files.

Code availability Not applicable.

\section{Declarations}

Ethics approval This article does not contain any studies with human participants or animals performed by any of the authors.

Conflicts of interest/Competing interests Ashley E. Sproles, Anthony Berndt, and Francis J. Fields all declare that they have no conflict of interest. Stephen Mayfield declares the following financial interests/ personal relationships which may be considered as potential competing interests: he holds an equity position in Algenesis Materials, a company that could potentially benefit from this publication.

Open Access This article is licensed under a Creative Commons Attribution 4.0 International License, which permits use, sharing, adaptation, distribution and reproduction in any medium or format, as long as you give appropriate credit to the original author(s) and the source, provide a link to the Creative Commons licence, and indicate if changes were made. The images or other third party material in this article are included in the article's Creative Commons licence, unless indicated otherwise in a credit line to the material. If material is not included in the article's Creative Commons licence and your intended use is not permitted by statutory regulation or exceeds the permitted use, you will need to obtain permission directly from the copyright holder. To view a copy of this licence, visit http://creativecommons.org/licenses/by/4.0/.

\section{References}

Aharoni A, Amitai G, Bernath K, Magdassi S, Tawfik DS (2005) Highthroughput screening of enzyme libraries: thiolactonases evolved by fluorescence-activated sorting of single cells in emulsion compartments. Chem Biol 12:1281-1289. https://doi.org/10.1016/j. chembiol.2005.09.012

Berthold P, Schmitt R, Mages W (2002) An engineered Streptomyces hygroscopicus aph 7" gene mediates dominant resistance against hygromycin B in Chlamydomonas reinhardtii. Protist 153:401412. https://doi.org/10.1078/14344610260450136

Borowitzka MA (2013) High-value products from microalgae-their development and commercialisation. J Appl Phycol 25:743-756. https://doi.org/10.1007/s10811-013-9983-9

Cagnon C, Mirabella B, Nguyen HM, Beyly-Adriano A, Bouvet S, Cuiné S, Beisson F, Peltier G, Li-Beisson Y (2013) Development of a forward genetic screen to isolate oil mutants in the green microalga Chlamydomonas reinhardtii. Biotechnol Biofuels 6(1):1-12. https://doi.org/10.1186/1754-6834-6-178

Cheah WY, Loke Show P, Chang J-S, Ling C, Juan C (2014) Biosequestration of atmospheric $\mathrm{CO} 2$ and flue gas-containing $\mathrm{CO} 2$ by microalgae. https://doi.org/10.1016/j.biortech.2014.11.026

Chen W, Zhang C, Song L, Sommerfeld M, Hu Q (2009) A highthroughput Nile red method for quantitative measurement of neutral lipids in microalgae. J Microbiol Methods 77:41-47. https:// doi.org/10.1016/j.mimet.2009.01.001
Chew KW, Yap JY, Show PL, Suan NH, Juan JC, Ling TC, Lee DJ, Chang JS (2017) Microalgae biorefinery: high value products perspectives. Bioresour Technol 229:53-62. https://doi.org/10.1016/j. biortech.2017.01.006

Daugherty PS (2007) Protein engineering with bacterial display. Curr Opin Struct Biol 17:474-480. https://doi.org/10.1016/j.sbi.2007. 07.004

de Carpentier F, Le Peillet J, Boisset ND, Crozet P, Lemaire SD, Danon A (2020) Blasticidin S Deaminase: A new efficient selectable marker for Chlamydomonas reinhardtii. Front Plant Sci 11:1-8. https://doi.org/10.3389/fpls.2020.00242

Dismukes GC, Carrieri D, Bennette N, Ananyev GM, Posewitz MC (2008) Aquatic phototrophs: efficient alternatives to land-based crops for biofuels. Curr Opin Biotechnol 19:235-240. https://doi. org/10.1016/j.copbio.2008.05.007

Dyo YM, Purton S (2018) The algal chloroplast as a synthetic biology platform for production of therapeutic proteins. Microbiol (united Kingdom) 164:113-121. https://doi.org/10.1099/mic.0.000599

Eichler-Stahlberg A, Weisheit W, Ruecker O, Heitzer M (2009) Strategies to facilitate transgene expression in Chlamydomonas reinhardtii. Planta 229(4):873-883

Fields FJ, Ostrand JT, Tran M, Mayfield SP (2019) Nuclear genome shuffling significantly increases production of chloroplast-based recombinant protein in Chlamydomonas reinhardtii. Algal Res 41:101523. https://doi.org/10.1016/j.algal.2019.101523

Fields FJ, Lejzerowicz F, Schroeder D, Ngoi SM, Tran M, McDonald D, Jiang L, Chang JT, Knight R, Mayfield S (2020) Effects of the microalgae Chlamydomonas on gastrointestinal health. J Funct Foods 65(103738):1-10. https://doi.org/10.1016/j.jff.2019.103738

Gao F, Teles (Cabanelas, ITD) I, Ferrer-Ledo N, Wijffels RH, Barbosa MJ (2020) Production and high throughput quantification of fucoxanthin and lipids in Tisochrysis lutea using single-cell fluorescence. Bioresour Technol 318:4-11. https://doi.org/10. 1016/j.biortech.2020.124104

Gao F, Sá M, Cabanelas ITD, Wijffels RH, Barbosa MJ (2021) Improved fucoxanthin and docosahexaenoic acid productivities of a sorted self-settling Tisochrysis lutea phenotype at pilot scale. Bioresour Technol 325(124725):1-10. https://doi.org/10. 1016/j.biortech.2021.124725

Georgianna DR, Hannon MJ, Marcuschi M, Wu S, Botsch K, Lewis AJ, Hyun J, Mendez M, Mayfield SP (2013) Production of recombinant enzymes in the marine alga Dunaliella tertiolecta. Algal Res 2:2-9. https://doi.org/10.1016/j.algal.2012.10.004

Gonzalez-Ballester D, Pootakham W, Mus F, Yang W, Catalanotti C, Magneschi L, De Montaigu A, Higuera JJ, Prior M, Galván $\mathrm{A}$, Fernandez E, Grossman AR (2011) Reverse genetics in Chlamydomonas: a platform for isolating insertional mutants. Plant Methods 7:1-13. https://doi.org/10.1186/1746-4811-7-24

Harris EH (2009) The Chlamydomonas sourcebook: introduction to Chlamydomonas and its laboratory use, vol 1. Elsevier Science, Netherlands

Haycock JW (1993) Polyvinylpyrrolidone as a blocking agent in immunochemical studies. Anal Biochem 208:397-399

Herrero M, Ibáñez E (2015) Green processes and sustainability: an overview on the extraction of high added-value products from seaweeds and microalgae. J Supercrit Fluids 96:211-216. https:// doi.org/10.1016/j.supflu.2014.09.006

Hyka P, Lickova S, Přibyl P, Melzoch K, Kovar K (2013) Flow cytometry for the development of biotechnological processes with microalgae. Biotechnol Adv 31:2-16. https://doi.org/10.1016/j. biotechadv.2012.04.007

Iomini C, Li L, Mo W, Dutcher SK, Piperno G (2006) Two flagellar genes, AGG2 and AGG3, mediate orientation to light in Chlamydomonas. Curr Biol 16:1147-1153. https://doi.org/10.1016/j. cub.2006.04.035 
Jinkerson RE, Jonikas MC (2015) Molecular techniques to interrogate and edit the Chlamydomonas nuclear genome. Plant J 82:393-412. https://doi.org/10.1111/tpj.12801

Kindle KL, Richards KL, Stern DB (1991) Engineering the chloroplast genome: techniques and capabilities for chloroplast transformation in Chlamydomonas reinhardtii. Proc Natl Acad Sci 88(5):1721-1725

Khoo HH, Koh CY, Shaik MS, Sharratt PN (2013) Bioenergy coproducts derived from microalgae biomass via thermochemical conversion-life cycle energy balances and $\mathrm{CO} 2$ emissions. Bioresour Technol 143:298-307. https://doi.org/10.1016/j.biort ech.2013.06.004

Koblenz B, Schoppmeier J, Grunow A, Lechtreck KF (2003) Centrin deficiency in Chlamydomonas causes defects in basal body replication, segregation and maturation. J Cell Sci 116:2635-2646. https://doi.org/10.1242/jcs.00497

Kwon KC, Lamb A, Fox D, Porphy Jegathese SJ (2019) An evaluation of microalgae as a recombinant protein oral delivery platform for fish using green fluorescent protein (GFP). Fish Shellfish Immunol 87:414-420. https://doi.org/10.1016/j.fsi. 2019.01.038

Ladygin VG, Boutanaev AM (2002) Transformation of Chlamydomonas reinhardtii $\mathrm{CW}-15$ with the hygromycin phosphotransferase gene as a selectable marker. Russ J Genet 38:10091014. https://doi.org/10.1023/A:1020279429009

Lam A, St-Pierre F, Gong Y, Marshall JD, Cranfill PJ, Baird MA, McKeown MR, Wiedenmann J, Davidson MW, Schnitzer MJ, Tsien RY, Lin MZ (2012) Improving FRET dynamic range with bright green and red fluorescent proteins. Nat Methods 9:10051012. https://doi.org/10.1073/pnas.62.4.1203

Lauersen KJ, Kruse O, Mussgnug JH (2015) Targeted expression of nuclear transgenes in Chlamydomonas reinhardtii with a versatile, modular vector toolkit. Appl Microbiol Biotechnol 99:3491-3503. https://doi.org/10.1007/s00253-014-6354-7

León-Bañares R, González-Ballester D, Galván A, Fernández E (2004) Transgenic microalgae as green cell-factories. Trends Biotechnol 22:45-52. https://doi.org/10.1016/j.tibtech.2003.11.003

Li X, Zhang R, Patena W, Gang SS, Blum SR, Ivanova N, Yue R, Robertson JM, Lefebvre PA, Fitz-Gibbon ST, Grossman AR, Jonikas MC (2016) An indexed, mapped mutant library enables reverse genetics studies of biological processes in Chlamydomonas reinhardtii. Plant Cell 28:367-387. https://doi.org/10.1105/tpc.15. 00465

Life Technologies Corporation (2013) GeneArt ® MAX efficiency (B) Transformation reagent for algae: user manual. ThermoFisher Scientific. Publication Number MAN0009795

Lingg N, Zhang P, Song Z, Bardor M (2012) The sweet tooth of biopharmaceuticals: importance of recombinant protein glycosylation analysis. Biotechnol J 7(12):1462-1472

López Barreiro D, Samorì C, Terranella G, Hornung U, Kruse A, Prins W (2014) Assessing microalgae biorefinery routes for the production of biofuels via hydrothermal liquefaction. Bioresour Technol 174:256-265. https://doi.org/10.1016/j.biortech.2014.10.031

Makino T, Skretas G, Georgiou G (2011) Strain engineering for improved expression of recombinant proteins in bacteria. Microb Cell Fact 10:1-10. https://doi.org/10.1186/1475-2859-10-32

Manuell AL, Beligni MV, Elder JH, Siefker DT, Tran M, Weber A, McDonald TL, Mayfield SP (2007) Robust expression of a bioactive mammalian protein in Chlamydomonas chloroplast. Plant Biotechnol J 5:402-412. https://doi.org/10.1111/j.1467-7652. 2007.00249.x

Mastrobattista E, Taly V, Chanudet E, Treacy P, Kelly BT, Griffiths AD (2005) High-throughput screening of enzyme libraries: in vitro evolution of a $\beta$-galactosidase by fluorescence-activated sorting of double emulsions. Chem Biol 12:1291-1300. https://doi.org/ 10.1016/j.chembiol.2005.09.016
Maul JE, Lilly JW, Cui L, DePamphilis CW, Miller W, Harris EH, Stern DB (2002) The Chlamydomonas reinhardtii plastid chromosome: islands of genes in a sea of repeats. Plant Cell 14:26592679. https://doi.org/10.1105/tpc.006155

Mayfield SP, Manuell AL, Chen S, Wu J, Tran M, Siefker D, Muto M, Marin-Navarro J (2007) Chlamydomonas reinhardtii chloroplasts as protein factories. Curr Opin Biotechnol 18:126-133. https://doi. org/10.1016/j.copbio.2007.02.001

Mendoza H, de la Jara A, Freijanes K, Carmona L, Ramos AA, de Sousa DV, Serafim Varela JC (2008) Characterization of Dunaliella salina strains by flow cytometry: a new approach to select carotenoid hyperproducing strains. Electron J Biotechnol 11(4):5-6. https://doi.org/10.2225/vol11/issue4-fulltext-2

Merchant SS, Prochnik SE, Vallon O, Harris EH, Karpowicz SJ, Witman GB, Terry A, Salamov A, Fritz-Laylin LK, MaréchalDrouard L, Marshall WF, Qu L-H, Nelson DR, Sanderfoot AA, Spalding MH, Kapitonov VV, Ren Q, Ferris P, Lindquist E, Shapiro H, Lucas SM, Grimwood J, Schmutz J, Team CA, Team JA, Grigoriev IV, Rokhsar DS, Grossman AR (2007) The Chlamydomonas genome reveals the evolution of key animal and plant functions. Science 318:245-250. https://doi.org/10.1126/science. 1143609.The

Meslet-Cladière L, Vallon O (2011) Novel shuttle markers for nuclear transformation of the green alga Chlamydomonas reinhardtii. Eukaryot Cell 10:1670-1678. https://doi.org/10.1128/EC. 05043-11

Montero MF, Aristizábal M, García Reina G (2011) Isolation of high-lipid content strains of the marine microalga Tetraselmis suecica for biodiesel production by flow cytometry and singlecell sorting. J Appl Phycol 23:1053-1057. https://doi.org/10.1007/ s10811-010-9623-6

Moreno-Garcia L, Adjallé K, Barnabé S, Raghavan GSV (2017) Microalgae biomass production for a biorefinery system: recent advances and the way towards sustainability. Renew Sustain Energy Rev 76:493-506. https://doi.org/10.1016/j.rser.2017.03. 024

Murbach TS, Glávits R, Endres JR, Hirka G, Vértesi A, Béres E, Szakonyiné IP (2018) A toxicological evaluation of Chlamydomonas reinhardtii, a Green Algae. Int J Toxicol 37:53-62. https://doi.org/ $10.1177 / 1091581817746109$

Neupert J, Karcher D, Bock R (2009) Generation of Chlamydomonas strains that efficiently express nuclear transgenes. Plant J 57:1140 1150. https://doi.org/10.1111/j.1365-313X.2008.03746.x

Neupert J, Shao N, Lu Y, Bock R (2012) Genetic transformation of the model green alga Chlamydomonas reinhardtii. In: Dunwell J, Wetten A (eds) Transgenic plants. Methods in molecular biology (Methods and Protocols), vol 847. Humana Press

Norrander J, Kempe T, Messing J (1983) Construction of improved M13 vectors using oligonucleotide-directed mutagenesis. Gene 26:101-106

Pereira H, Barreira L, Mozes A, Florindo C, Polo C, Duarte CV, Custádio L, Varela J (2011) Microplate-based high throughput screening procedure for the isolation of lipid-rich marine microalgae. Biotechnol Biofuels 4:1-12. https://doi.org/10.1186/ 1754-6834-4-61

Pereira H, Schulze PSC, Schüler LM, Santos T, Barreira L, Varela J (2018) Fluorescence activated cell-sorting principles and applications in microalgal biotechnology. Algal Res 30:113-120. https:// doi.org/10.1016/j.algal.2017.12.013

Potvin G, Zhang Z (2010) Strategies for high-level recombinant protein expression in transgenic microalgae: a review. Biotechnol Adv 28(6):910-918

Rasala BA, Mayfield SP (2015) Photosynthetic biomanufacturing in green algae; production of recombinant proteins for industrial, nutritional, and medical uses. Photosynth Res 123:227-239. https://doi.org/10.1007/s11120-014-9994-7 
Rasala BA, Lee PA, Shen Z, Briggs SP, Mendez M, Mayfield SP (2012) Robust expression and secretion of Xylanase1 in Chlamydomonas reinhardtii by fusion to a selection gene and processing with the FMDV 2A peptide. PLoS One 7(8):e43349

Rasala BA, Barrera DJ, Ng J, Plucinak TM, Rosenberg JN, Weeks DP, Oyler GA, Peterson TC, Haerizadeh F, Mayfield SP (2013) Expanding the spectral palette of fluorescent proteins for the green microalga Chlamydomonas reinhardtii. Plant J 74:545-556. https://doi.org/10.1111/tpj.12165

Remacle C, Cardol P, Coosemans N, Gaisne M, Bonnefoy N (2006) High-efficiency biolistic transformation of Chlamydomonas mitochondria can be used to insert mutations in complex I genes. Proc Natl Acad Sci 103(12):4771-4776

Scranton MA, Ostrand JT, Fields FJ, Mayfield SP (2015) Chlamydomonas as a model for biofuels and bio-products production. Plant J 82:523-531. https://doi.org/10.1111/tpj.12780

Scranton MA, Ostrand JT, Georgianna DR, Lofgren SM, Li D, Ellis RC, Carruthers DN, Dräger A, Masica DL, Mayfield SP (2016) Synthetic promoters capable of driving robust nuclear gene expression in the green alga Chlamydomonas reinhardtii. Algal Res 15:135-142. https://doi.org/10.1016/j.algal.2016. 02.011

Sheehan J, Dunahay T, Benemann J, Roessler P (1998) A look back at the US Department of Energy's Aquatic Species Program: biodiesel from algae. Natl Renew Energy Lab 328:1-294

Smalley T, Fields FJ, Berndt AJE, Ostrand JT, Heredia V, Mayfield SP (2020) Improving biomass and lipid yields of Desmodesmus armatus and Chlorella vulgaris through mutagenesis and highthroughput screening. Biomass Bioenerg 142:105755. https://doi. org/10.1016/j.biombioe.2020.105755

Soria-Guerra RE, Ramírez-Alonso JI, Ibáñez-Salazar A, Govea-Alonso DO, Paz-Maldonado LMT, Bañuelos-Hernández B, Korban SS, Rosales-Mendoza S (2014) Expression of an HBcAg-based antigen carrying angiotensin II in Chlamydomonas reinhardtii as a candidate hypertension vaccine. Plant Cell Tissue Organ Cult 116:133-139. https://doi.org/10.1007/s11240-013-0388-x

Specht EA, Mayfield SP (2014) Algae-based oral recombinant vaccines. Front Microbiol 5:1-7. https://doi.org/10.3389/fmicb. 2014.00060

Sproles AE, Fields FJ, Smalley TN, Le CH, Badary A, Mayfield SP (2021) Recent advancements in the genetic engineering of microalgae. Algal Res 53:102158. https://doi.org/10.1016/j.algal. 2020.102158
Stephens E, Ross IL, King Z, Mussgnug JH, Kruse O, Posten C, Borowitzka MA, Hankamer B (2010) An economic and technical evaluation of microalgal biofuels. Nat Biotechnol 28:126-128. https://doi.org/10.1038/nbt0210-126

Terashima M, Freeman ES, Jinkerson RE, Jonikas MC (2015) A fluorescence-activated cell sorting-based strategy for rapid isolation of high-lipid Chlamydomonas mutants. Plant J 81:147-159. https:// doi.org/10.1111/tpj.12682

Vahrenholz C, Riemen G, Pratje E, Dujon B, Michaelis G (1993) Mitochondrial DNA of Chlamydomonas reinhardtii: the structure of the ends of the linear $15.8-\mathrm{kb}$ genome suggests mechanisms for DNA replication. Curr Genet 24:241-247. https://doi.org/10. 1007/BF00351798

Velmurugan N, Sung M, Yim SS, Park MS, Yang JW, Jeong KJ (2013) Evaluation of intracellular lipid bodies in Chlamydomonas reinhardtii strains by flow cytometry. Bioresour Technol 138:30-37. https://doi.org/10.1016/j.biortech.2013.03.078

Waldo GS, Standish BM, Berendzen J, Terwilliger TC (1999) Rapid protein-folding assay using green fluorescent protein. Nat Biotechnol 17:691-695. https://doi.org/10.1038/10904

Wijffels RH, Barbosa MJ (2010) An outlook on microalgal biofuels. Science 329(5993):796-799. https://doi.org/10.1126/science.1189003

Xie B, Stessman D, Hart JH, Dong H, Wang Y, Wright DA, Nikolau BJ, Spalding MH, Halverson LJ (2014) High-throughput fluorescence-activated cell sorting for lipid hyperaccumulating Chlamydomonas reinhardtii mutants. Plant Biotechnol J 12:872-882. https://doi.org/10.1111/pbi.12190

Yamada K, Suzuki H, Takeuchi T, Kazama Y, Mitra S, Abe T, Goda K, Suzuki K, Iwata O (2016) Efficient selective breeding of live oil-rich Euglena gracilis with fluorescence-activated cell sorting. Sci Rep 6:2-9. https://doi.org/10.1038/srep26327

Yamasaki T, Miyasaka H, Ohama T (2008) Unstable RNAi effects through epigenetic silencing of an inverted repeat transgene in Chlamydomonas reinhardtii. Genetics 180:1927-1944. https://doi. org/10.1534/genetics.108.092395

Zhang R, Patena W, Armbruster U, Gang SS, Blum SR, Jonikas MC (2014) High-throughput genotyping of green algal mutants reveals random distribution of mutagenic insertion sites and endonucleolytic cleavage of transforming DNA. Plant Cell 26:1398-1409. https://doi.org/10.1105/tpc.114.124099

Publisher's note Springer Nature remains neutral with regard to jurisdictional claims in published maps and institutional affiliations. 